\title{
Separation of Alcaligenes denitrificans sp. nov., nom. rev. from Alcaligenes faecalis on the Basis of DNA Base Composition, DNA Homology, and Nitrate Reduction
}

\author{
H.-J. RÜGER* AND T. L. TAN \\ Institut für Meeresforschung, Am Handelshafen 12, D-2850 Bremerhaven, Federal Republic of Germany
}

\begin{abstract}
"Alcaligenes denitrificans" Leifson and Hugh 1954 was not included in the Approved Lists of Bacterial Names and hence has no standing in bacteriological nomenclature. However, Alcaligenes faecalis DSM 30026 ("A. denitrificans" Leifson and Hugh 1954, type strain) has a DNA base composition of $69.1 \pm 0.3$ mol\% $\mathrm{G}+\mathrm{C}$, whereas $A$. faecalis DSM 30030 (type strain) and A. faecalis DSM 30033 ("A. odorans," type strain) have $57.6 \pm 0.5$ and $55.3 \pm 0.8 \mathrm{~mol} \% \mathrm{G}+\mathrm{C}$, respectively. DNA hybridization revealed homologies of $27 \%$ between $A$. faecalis DSM $30026^{\mathrm{T}}$ and strain DSM $30030^{\mathrm{T}}, 26 \%$ between $A$. faecalis DSM $30026^{\mathrm{T}}$ and strain DSM $30033^{\mathrm{T}}$, but $71 \%$ between strains DSM $30030^{\mathrm{T}}$ and DSM $30033^{\mathrm{T}}$. A yellow fluorescent pigment in King medium B was produced by A. faecalis strains DSM $30030^{\mathrm{T}}$ and DSM $30033^{\mathrm{T}}$ but not by strain DSM $30026^{\mathrm{T}}$. Only A. faecalis DSM $30026^{\mathrm{T}}$ was able to grow with nitrate or nitrite as sole source of nitrogen and to reduce nitrate to nitrite and gas. All three strains reduced nitrite to gas, but an additional nitrogen source, e.g., ammonium ion, was necessary for the growth of strains DSM $30030^{\mathrm{T}}$ and DSM $30033^{\mathrm{T}}$. In mineral media, the nitrate reduction to nitrite and gas has been shown to be reproducible. Based on the differences among A. faecalis DSM 30026 and both $A$. faecalis DSM $30030^{\mathrm{T}}$ and DSM $30033^{\mathrm{T}}$, the revival of the name Alcaligenes denitrificans is herein proposed.
\end{abstract}

Leifson and Hugh (11) described two strains which reduced nitrate to nitrite and gas as belonging to a new species, "Alcaligenes denitrificans." NCTC 8582 was designated the type strain. Based on biochemical and nutritional characteristics, Hendrie et al. (9) proposed " $A$. denitrificans," "A. odorans" (Málek and Kazdová-Kožišková) Málek, Radochovà, and Lysenko 1963, and "Achromobacter arsenoxydans-tres" Turner 1954 as subjective synonyms of A. faecalis Castellani and Chalmers 1919. The description of $A$. faecalis given in Bergey's Manual of Determinative Bacteriology, 8th ed. (10) follows the proposal of Hendrie et al. (9). The rejection of " $A$. denitrificans" was reinforced by the exclusion of this name from the Approved Lists of Bacterial Names published in $1980(20)$.

In addition to other characteristics, Pichinoty et al. (17) reported a DNA base ratio of 67.3 mol\% $\mathrm{G}+\mathrm{C}$ for " $A$. denitrificans" CIP $7715^{\mathrm{T}}$ $\left(=\mathrm{DSM} 30026^{\mathrm{T}}\right)$ and a DNA base ratio of 56.1 mol\% $\mathrm{G}+\mathrm{C}$ for $A$. faecalis CIP $6080^{\mathrm{T}}$ (=DSM $30030^{\mathrm{T}}$ ), regarded as " $A$. odorans" by Pichinoty et al. (17).

Bacteria whose genomic DNAs differ by more than 4 to $5 \mathrm{~mol} \% \mathrm{G}+\mathrm{C}(2)$ or by $10 \mathrm{~mol} \% \mathrm{G}+\mathrm{C}$ (23) should not be considered members of the same species.
To define the relationships among $A$. faecalis ("A. denitrificans") DSM $30026^{\mathrm{T}}$, A. faecalis DSM 30030 (type strain), and A. faecalis ("A. odorans") DSM $30033^{\mathrm{T}}$, DNA base analyses, DNA hybridization experiments, nitrate reduction to nitrite and gas, and other identification procedures were performed.

\section{MATERIALS AND METHODS}

Bacterial strains. The following strains were used in this study.

Alcaligenes faecalis DSM 30030 (=ATCC 8750, $=$ CIP $6080,=$ NCIB 8156). Strain ATCC 8750, originally the reference strain of $A$. faecalis $(9,10)$, has been established as the type strain (20).

Alcaligenes faecalis DSM 30033 (=CCEB 554, $=$ ATCC 15554). Strain CCEB 554 is the type strain of "A. odorans" (12), which is now regarded as a subjective synonym of $A$. faecalis $(9,10)$.

Alcaligenes faecalis DSM 30026 (=NCTC 8582, $=$ ATCC 15173, =CIP 7715). Strain NCTC 8582 is the type strain of "A. denitrificans" (11).

Cultures of these strains were obtained from the Deutsche Sammlung von Mikroorganismen, Göttingen, Germany.

The abbreviations used in strain designations are: ATCC, American Type Culture Collection, Rockville, Md.; CCEB, Culture Collection of Entomogenous Bacteria, Prague, Czechoslovakia; CIP, Collection de l'Institut Pasteur, Paris, France; DSM, Deutsche Sammlung von Mikroorganismen, Göttingen, Federal 
Republic of Germany; NCIB, National Collection of Industrial Bacteria, Aberdeen, Scotland; and NCTC, National Collection of Type Cultures, Central Public Health Laboratory, London, England.

Biochemical tests. The media used for determining the biochemical and nutritional characteristics of the strains have been previously described (24). The media used for detecting the amino acid decarboxylases, lipolysis, and alginate digestion were reported by Rüger and Richter (18). The growth experiments with various carbon sources were carried out in the artificial seawater medium described below (ASM + $\mathrm{NH}_{4}{ }^{+}$, but with the respective carbon source instead of succinate). DNase activity was determined on Desoxyribonuclease Testagar (E. Merck AG, Darmstadt, Federal Republic of Germany).

DNA base composition. DNA was isolated according to the method of Marmur (14) from cells grown in ASM $+\mathrm{NH}_{4}^{+}$as described below, but with sodium glutamate $(4 \mathrm{~g} /$ /iter $)$ and yeast extract $(50 \mathrm{mg} / \mathrm{liter})$ instead of ammonium sulfate, sodium succinate, and vitamins. As the terminal electron acceptor instead of oxygen, $1 \mathrm{~g}$ of $\mathrm{KNO}_{2}$ and $1 \mathrm{~g}$ of $\mathrm{KNO}_{3}$ were added per liter for growing strains DSM $30030^{\mathrm{T}}$ and DSM $30033^{\mathrm{T}}$ and strain DSM $30026^{\mathrm{T}}$, respectively. The medium $(750 \mathrm{ml})$ was filled into 1-liter Erlenmeyer flasks and inoculated with $50 \mathrm{ml}$ of a preculture grown overnight in the same medium. The cultures were incubated at $33^{\circ} \mathrm{C}$ for 4 days without shaking. From 4.5 liter of medium, about $2 \mathrm{~g}$ (wet weight) of cells were harvested by centrifugation. The use of these growth media and conditions reduced the production of an intracellular slime, which otherwise decreased the yield of DNA by adsorbance. Because the slime formed a resilient substance at $60^{\circ} \mathrm{C}$, the cells were lysed overnight at $33^{\circ} \mathrm{C}$ with sodium lauryl sulfate.

The melting temperature $\left(T_{m}\right)$ of the DNA was determined by the method of Marmur and Doty (15) with a recording Gilford spectrophotometer (no. 250) equipped with a reference compensator, a thermocuvette, and a thermoprogrammer. The $\mathrm{G}+\mathrm{C}$ content of the DNA was calculated from the $T_{m}$ by the equation given by De Ley (5). It was necessary to use $0.1 \times$ standard saline citrate (SSC) buffer and equation 3 of Mandel and Marmur (13) for determining the high $\mathrm{G}+\mathrm{C}$ content of DNA in strain DSM $30026^{\mathrm{T}}$. DNA from Escherichia coli $\mathrm{K}-12$ was used as a standard. The DNA base ratio for each strain was calculated from nine test results.

DNA hybridization. DNA hybridization was measured from renaturation rates according to the methods and conditions reported by De Ley et al. (6) and Gillis et al. (8). The isolated DNA was dialyzed against 2 liters of $2 \times \mathrm{SSC}$ buffer for 3 days at $4^{\circ} \mathrm{C}$. The buffer was replaced twice by fresh buffer solutions after 24 and $48 \mathrm{~h}$. The DNA was then sheared by passing it through a French pressure cell (catalog no. 4-3399; American Instrument Co., Inc., Silver Spring, Md.) at 1,075 bar in the liquid.

Normally, optimal renaturation rates are achieved in $2 \times$ SSC buffer, but the $T_{m}$ is increased by about $4^{\circ} \mathrm{C}$ if the cation concentration is doubled (8). For technical reasons, $T_{m}$ 's exceeding $100^{\circ} \mathrm{C}$ cannot be applied in the Gilford thermocuvette, and, therefore, the denaturation temperatures were lowered $16^{\circ} \mathrm{C}$ by the addition of $25 \%(\mathrm{vol} / \mathrm{vol})$ formamide to the buffer.
The sample compartments of the thermocuvette were filled as follows: compartment $1,2 \times$ SSC buffer as a blank; compartment 2 , DNA sample A; compartment 3 , a mixture $(1: 1)$ of DNA samples $A$ and $B$; and compartment 4, DNA sample B. The denaturation temperature was adjusted to $96^{\circ} \mathrm{C}$ and maintained for $30 \mathrm{~min}$ after the maximal hyperchromicity had been achieved. To avoid the high absorbance of formamide at $260 \mathrm{~nm}$, the optical measurements were performed at $270 \mathrm{~nm}$ (1). The temperature was then rapidly adjusted to $62^{\circ} \mathrm{C}$, i.e., the average renaturation temperature (8) of DNA from strains DSM $30026^{\mathrm{T}}$ and DSM $30033^{\mathrm{T}}$ was lowered by $16^{\circ} \mathrm{C}$. The change in absorbancy, reaching linearity after a few minutes, was recorded for $40 \mathrm{~min}$. Renaturation rates were determined directly from the renaturation curves in the time intervals between 6 and $36 \mathrm{~min}$ and 8 and 36 min after cooling the samples. The degree of DNADNA binding was calculated from the renaturation rates with equation 20 of De Ley et al. (6). Five renaturation experiments were performed for each combination of strains

Nitrate reduction to nitrite and gas and nitrite reduction to gas. The medium composition used was based on an artificial seawater solution described by Burkholder (4), but with half the concentration of mineral salts. The constituents of the medium in $1,000 \mathrm{ml}$ of distilled water were: $\mathrm{NaCl}, 11.738 \mathrm{~g} ; \mathrm{KCl}, 0.332 \mathrm{~g}$; $\mathrm{KBr}, 0.048 \mathrm{~g} ; \mathrm{MgCl}_{2} \cdot 6 \mathrm{H}_{2} \mathrm{O}, 5.305 \mathrm{~g} ; \mathrm{SrCl}_{2} \cdot 6 \mathrm{H}_{2} \mathrm{O}$, $0.020 \mathrm{~g} ; \mathrm{CaCl}_{2} \cdot 2 \mathrm{H}_{2} \mathrm{O}, 0.7345 \mathrm{~g} ; \mathrm{Na}_{2} \mathrm{SO}_{4}, 1.9585 \mathrm{~g}$; $\mathrm{NaHCO}_{3}, 0.096 \mathrm{~g} ; \mathrm{H}_{3} \mathrm{BO}_{3}, 0.013 \mathrm{~g} ; \mathrm{K}_{2} \mathrm{HPO}_{4}, 0.020 \mathrm{~g}$; $\left(\mathrm{NH}_{4}\right)_{2} \mathrm{SO}_{4}, 1.0 \mathrm{~g} ; \mathrm{Fe}(\mathrm{III})$-citrate, $0.0007 \mathrm{~g}$; and sodium succinate (carbon source), $2.0 \mathrm{~g}$. A vitamin stock solution was added $(2 \mathrm{ml})$ containing per $100 \mathrm{ml}$ of distilled water: biotin, $0.2 \mathrm{mg}$; nicotinic acid, $2 \mathrm{mg}$; thiamine dichloride, $1 \mathrm{mg}$; $p$-aminobenzoic acid, $1 \mathrm{mg}$; pantothenic acid (calcium salt), $0.5 \mathrm{mg}$; pyridoxamine, $5 \mathrm{mg}$; vitamin $\mathrm{B}_{12}, 2 \mathrm{mg}$; riboflavin, $1 \mathrm{mg}$; folic acid, $0.3 \mathrm{mg}$; and myo-inositol, $0.1 \mathrm{mg}$. The $\mathrm{pH}$ was adjusted to 7.8. This medium, abbreviated $\mathrm{ASM}+\mathrm{NH}_{4}{ }^{+}$, was used for growing the precultures ( 2 days incubation at $24^{\circ} \mathrm{C}$ ).

Nitrate reduction to nitrite and gas was determined in $\mathrm{ASM}+\mathrm{NH}_{4}{ }^{+}$medium containing $0.5 \mathrm{~g}$ or $1.0 \mathrm{~g}$ of $\mathrm{KNO}_{3}$ per liter $\left(\mathrm{ASM}+\mathrm{NH}_{4}{ }^{+}+\mathrm{NO}_{3}{ }^{-}\right)$and in the $\mathrm{ASM}+\mathrm{NH}_{4}^{+}+\mathrm{NO}_{3}^{-}$medium without ammonium ion (ASM $+\mathrm{NO}_{3}{ }^{-}$). A Durham tube was inserted into each test tube, which contained $10 \mathrm{ml}$ of the medium. The media were inoculated with 1 drop of the precultures, and after 1,2 , and 3 days at $24^{\circ} \mathrm{C}$, nitrite formation was tested with Merckoquant 10007 nitrite test sticks (16); gas formation by denitrification was detected in the Durham tubes after 7,9, and 14 days of incubation.

Nitrite reduction to gas was observed in ASM + $\mathrm{NH}_{4}{ }^{+}$containing $0.5 \mathrm{~g}$ of $\mathrm{KNO}_{2}$ per liter (ASM + $\mathrm{NH}_{4}{ }^{+}+\mathrm{NO}_{2}{ }^{-}$) and in the ASM $+\mathrm{NH}_{4}{ }^{+}+\mathrm{NO}_{2}{ }^{-}$ medium without ammonium ion ( $\left.\mathrm{ASM}+\mathrm{NO}_{2}^{-}\right)$. $\mathrm{Gas}$ formation in the Durham tubes was detected after 7,9 , and 14 days of incubation at $24^{\circ} \mathrm{C}$.

Nitrate and nitrite assimilation. Growth in ASM + $\mathrm{NO}_{3}{ }^{-}$and in $\mathrm{ASM}+\mathrm{NO}_{2}^{-}$media after 7 days of incubation at $24^{\circ} \mathrm{C}$ was used as an indication of the ability of the bacteria to assimilate nitrate or nitrite. Turbidity measurements at $578 \mathrm{~nm}$ were used as evidence of growth. A strain was regarded as assimi- 
lating nitrate or nitrite if the turbidity increased 0.1 unit or more.

\section{RESULTS}

The characteristics useful in differentiating between A. faecalis DSM $30030^{\mathrm{T}}$, A. faecalis ("A. odorans") DSM $30033^{\mathrm{T}}$, and $A$. faecalis ("A. denitrificans") DSM $30026^{\mathrm{T}}$ are listed in Table 1. Other diagnostic test results obtained with A. faecalis strains DSM $30030^{\mathrm{T}}$ and DSM $30033^{\mathrm{T}}$ were identical with those reported in the description of " $A$. denitrificans" at the end of this paper.

The results of the DNA hybridizations showed DNA homologies of $27 \pm 3.7 \%$ between strains DSM $30026^{\mathrm{T}}$ and DSM $30030^{\mathrm{T}}$ and of 26 $\pm 2.6 \%$ between strains DSM $30026^{\mathrm{T}}$ and DSM $30033^{\mathrm{T}}$. However, a DNA homology of $71 \pm$ $1.0 \%$ was found for strains DSM $30030^{\mathrm{T}}$ and DSM $30033^{\mathrm{T}}$.

The yellow fluorescent pigments (Table 1) produced by A. faecalis DSM $30030^{\mathrm{T}}$ and DSM $30033^{\mathrm{T}}$ in King medium B were probably fluorescein. This yellow fluorescence was observed at a wavelength of $360 \mathrm{~nm}$ (but not at $240 \mathrm{~nm}$ ) in a glass petri dish after removing the cover. In plastic petri dishes, pigment production was inhibited or delayed.

\section{DISCUSSION}

The differences and some similarities of the type strains of the three Alcaligenes species studied are listed in Table 1.

The DNA base compositions obtained are comparable with those reported in the literature for these strains $(7,9,10,17)$. Pichinoty et al. (17) reported $67.3 \mathrm{~mol} \% \mathrm{G}+\mathrm{C}$ for " $A$. denitrifcans" CIP $7715^{\mathrm{T}}$ (=DSM $30026^{\mathrm{T}}$ ) and $56.1 \mathrm{~mol} \%$ $\mathrm{G}+\mathrm{C}$ for A. faecalis CIP $6080^{\mathrm{T}}\left(=\mathrm{DSM} 30030^{\mathrm{T}}\right)$; the latter strain was assigned to "A. odorans" by Pichinoty et al. (17). According to De Ley et al. (7) and to Hendrie et al. (9), the DNAs of $A$. faecalis NCIB $8156^{\mathrm{T}}\left(=\mathrm{DSM} 30030^{\mathrm{T}}\right)$ and $A$. faecalis CCEB $554^{\mathrm{T}}\left(=\mathrm{DSM} 30033^{\mathrm{T}}\right)$ had 58.9 and $56.6 \mathrm{~mol} \% \mathrm{G}+\mathrm{C}$, respectively. Unfortunately, these publications $(7,9)$ did not contain any data about the DNA base composition of the type strain of " $A$. denitrificans.'

Further studies are necessary to define the taxonomic status of strains regarded as either $A$. faecalis or " $A$. denitrificans" and with DNA base compositions of about 64 to $65 \mathrm{~mol} \% \mathrm{G}+\mathrm{C}$ $(7,17)$.

A single-linkage dendrogram given by Seiler (19) shows 25 diagnostic characteristics out of 146 to be different among "A. denitrificans" DSM $30026^{\mathrm{T}}$ and the other two A. faecalis strains, DSM $30030^{\mathrm{T}}$ and DSM $30033^{\mathrm{T}}$. However, the author did not mention which characteristics were different. The distinctive characteris- tics found by Pichinoty et al. (17) for " $A$. denitrificans" DSM $30026^{\mathrm{T}}$ and A. faecalis DSM $30030^{\mathrm{T}}$ are listed after the description of " $A$. denitrificans" at the end of this paper.

Leifson and Hugh (11) described "A. denitrificans" NCTC $8582^{\mathrm{T}}$ as the type strain of a new species that reduced nitrate to nitrite and gas. According to Hendrie et al. (9), anaerobic respiration in the presence of nitrate in " $A$. denitrificans" NCTC $8582^{\mathrm{T}}$ may be lost on subculturing. This has been misinterpreted to mean that deni-

TABLE 1. Characteristics useful in differentiating A. faecalis DSM 30030 from “ A . denitrificans" DSM 30026

\begin{tabular}{|c|c|c|}
\hline \multirow[b]{2}{*}{ Characteristic } & \multicolumn{2}{|c|}{ Expression in: ${ }^{a}$} \\
\hline & $\begin{array}{l}\text { A. faecalis } \\
\text { DSM } 30030^{b}\end{array}$ & $\begin{array}{l}\text { A. denitrifi- } \\
\text { cans DSM } \\
30026\end{array}$ \\
\hline DNA $(\mathrm{mol} \% \mathrm{G}+\mathrm{C})$ & $57.6 \pm 0.5$ & $69.1 \pm 0.3$ \\
\hline $\begin{array}{l}\text { Yellow fluorescent pig- } \\
\text { ment in King medium } \\
\text { B }\end{array}$ & $+(7 \text { days })^{c}$ & - \\
\hline \multicolumn{3}{|l|}{$\begin{array}{l}\text { Nitrate reduction to } \\
\text { nitrite in: }\end{array}$} \\
\hline$\underset{\mathrm{NO}_{3}^{-}}{\mathrm{ASM}}+\mathrm{NH}_{4}^{+}+0.5 \mathrm{~g}$ & - & $+(2$ days $)$ \\
\hline$\underset{\mathrm{NO}_{3}}{\mathrm{ASM}}+\mathrm{NH}_{4}^{+}+1.0 \mathrm{~g}$ & - & $+(2$ days $)$ \\
\hline $\mathrm{ASM}+0.5 \mathrm{~g} \mathrm{NO}_{3}^{-}$ & No growth ${ }^{d}$ & $+(2$ days $)$ \\
\hline $\mathrm{ASM}+1.0 \mathrm{~g} \mathrm{NO}_{3}^{-}$ & No growth ${ }^{d}$ & $+(2$ days $)$ \\
\hline \multicolumn{3}{|l|}{$\begin{array}{l}\text { Nitrate reduction to } \\
\text { gas in: }\end{array}$} \\
\hline$\underset{\mathrm{NO}_{3}^{-}}{\mathrm{ASM}}+\mathrm{NH}_{4}^{+}+0.5 \mathrm{~g}$ & - & $+(9$ days $)$ \\
\hline $\begin{array}{l}\mathrm{ASM} \\
\mathrm{NO}_{3}^{-}\end{array}$ & N & 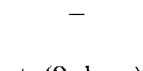 \\
\hline $\mathrm{ASM}+0.5 \mathrm{~g} \mathrm{NO}_{3}^{-}$ & No growth ${ }^{d}$ & $+(9$ days $)$ \\
\hline $\mathrm{ASM}+1.0 \mathrm{~g} \mathrm{NO}_{3}^{-}$ & No growth ${ }^{d}$ & $+(7$ days $)$ \\
\hline \multicolumn{3}{|l|}{$\begin{array}{l}\text { Nitrite reduction to } \\
\text { gas in: }\end{array}$} \\
\hline$\underset{\mathrm{NO}_{2}^{-}}{\mathrm{ASM}}+\mathrm{NH}_{4}^{+}+0.5 \mathrm{~g}$ & $+(7$ days $)$ & $+(7$ days $)$ \\
\hline $\mathrm{ASM}+0.5 \mathrm{~g} \mathrm{NO}_{2}^{-}$ & No growth ${ }^{e}$ & $+(7$ days $)$ \\
\hline \multicolumn{3}{|l|}{ Assimilation of nitrate in: } \\
\hline $\mathrm{ASM}+0.5 \mathrm{~g} \mathrm{NO}_{3}^{-}$ & $-f$ & $+(9$ days $)$ \\
\hline $\mathrm{ASM}+1.0 \mathrm{~g} \mathrm{NO}_{3}^{-}$ & $-f$ & $+(9$ days $)$ \\
\hline $\begin{array}{l}\text { Assimilation of nitrite in: } \\
\text { ASM }+0.5 \mathrm{~g} \mathrm{NO}_{2}^{-}\end{array}$ & $-f$ & $+(7$ days $)$ \\
\hline
\end{tabular}

${ }^{a}$ Symbols: + , positive test result; - , negative test result.

${ }^{b}$ Characteristics of $A$. faecalis DSM $30033^{\mathrm{T}}$ were identical to those of DSM 30030, but strain DSM 30033 has a $\mathrm{G}+\mathrm{C}$ mol\% of $55.3 \pm 0.8$.

c Numbers in parentheses indicate the incubation time required to detect positive results.

${ }^{d}$ Nitrate was not assimilated; as a consequence, the strain did not grow.

${ }^{e}$ Nitrite was not assimilated; as a consequence, the strain did not grow.

${ }^{f}$ Growth was used to measure assimilation of nitrate or nitrite. 
trification is an unstable characteristic and therefore not useful for differentiating " $A$. denitrificans" NCTC $8582^{\mathrm{T}}$ from A. faecalis. The strain was isolated before 1954 (11) and has been kept aerobically in our culture collection since 1978, and it is still able to denitrify. Stanier et al. (22) discussed the significance of denitrification and concluded that the ability to use nitrate instead of oxygen as a terminal electron acceptor is a characteristic of considerable taxonomic value among pseudomonads.

We found that the ability to denitrify is dependent on the composition of the test medium (see Table 1) and, for strain DSM $30026^{\mathrm{T}}$, upon the initial nitrate concentration. Strain DSM $30026^{\mathrm{T}}$ is able to denitrify in ASM $+\mathrm{NH}_{4}{ }^{+}+\mathrm{NO}_{3}{ }^{-}$and in $\mathrm{ASM}+\mathrm{NO}_{3}{ }^{-}$containing $0.5 \mathrm{~g}$ of nitrate per liter. The $1.0 \mathrm{~g}$ or $5.0 \mathrm{~g}$ of nitrate per liter in ASM $+\mathrm{NH}_{4}{ }^{+}+\mathrm{NO}_{3}{ }^{-}$or in the mineral medium of Pichinoty et al. (17) affected the growth of strain DSM $30026^{\mathrm{T}}$ and, therefore, gas production was absent.

As shown in Table 1, "A. denitrificans" DSM $30026^{\mathrm{T}}$ also reduces nitrate to nitrite in the medium containing $\mathrm{NH}_{4}{ }^{+}$. Therefore, a dissimilatory nitrate reductase is produced because assimilatory nitrate reductase is repressed by ammonium ion (3). The synthesis of assimilatory nitrate reductase in DSM $30026^{\mathrm{T}}$ cannot be proved by this method. According to Pichinoty et al. (17), nitrate reductase A, presumably a dissimilatory nitrate reductase, is produced by strain ATCC $15173^{\mathrm{T}}\left(=\mathrm{DSM} 30026^{\mathrm{T}}\right)$. A. faecalis DSM $30030^{\mathrm{T}}$ did not reduce nitrate to nitrite in $\mathrm{ASM}+\mathrm{NH}_{4}{ }^{+}+\mathrm{NO}_{3}{ }^{-}$and in $\mathrm{ASM}+\mathrm{NO}_{3}{ }^{-}$, and consequently both nitrate reductases are absent. The presence of an assimilatory nitrate reductase would cause growth of the cells and production of nitrite as an intermediate. These results are in agreement with those reported by Pichinoty et al. (17).

"A. denitrificans" DSM $30026^{\mathrm{T}}$ did assimilate nitrate (see Table 1). Surprisingly, Pichinoty et al. (17) reported "A. denitrificans" ATCC $15173^{\mathrm{T}}$ (=DSM $30026^{\mathrm{T}}$ ) and five strains belonging to their " $A$. odorans" group as organisms not able to assimilate nitrate. However, Pichinoty et al. used $5.0 \mathrm{~g}$ of $\mathrm{KNO}_{3}$ per liter in their medium.

"A. denitrificans" DSM $30026^{\mathrm{T}}$ assimilates nitrite and produces gas in ASM $+\mathrm{NO}_{2}{ }^{-}$and, therefore, an assimilatory and a dissimilatory nitrite reductase (3) are present. A dissimilatory nitrite reductase in strain DSM $30026^{\mathrm{T}}$ has been reported (17). A. faecalis DSM $30030^{\mathrm{T}}$ did not assimilate nitrate or nitrite, but gas was produced in $\mathrm{ASM}+\mathrm{NH}_{4}{ }^{+}+\mathrm{NO}_{2}{ }^{-}$, indicating that only a dissimilatory nitrite reductase was present (cf. Pichinoty et al. [17]). Preliminary tests revealed that the three strains investigated failed to grow in the ASM medium containing a $\mathrm{KNO}_{2}$ concentration of $1.0 \mathrm{~g} /$ liter, whereas considerable growth occurred with $0.5 \mathrm{~g}$ of $\mathrm{KNO}_{2}$ per liter. Therefore, this concentration was chosen for determining nitrite reduction to gas.

The agreement of nitrate reduction to nitrite, nitrate reduction to gas, and nitrite reduction to gas test results with those reported by Pichinoty et al. (17) demonstrates the reliability of these tests. The results are reproducible, but a mineral medium must be used. Sneath and Collins (21) reported the unreliability of nitrate reduction and denitrification tests, but their results were obtained with media containing peptone. Many bacterial strains produce ammonium ion from peptone, but ammonium ion is known to repress the assimilatory enzymes involved in nitrate or nitrite reduction (3).

The results presented in Table 1 and the DNA homology data confirm the combination of " $A$. odorans" with A. faecalis. The type strain of "A. denitrificans," however, cannot be united with $A$. faecalis. It is also not possible to transfer strain DSM $30026^{\mathrm{T}}$ to one of the other Alcaligenes species with $\mathrm{G}+\mathrm{C}$ contents of about $68 \mathrm{~mol} \%$ because A. eutrophus, A. latus, $A$. paradoxus, and $A$. ruhlandii are autotrophic organisms, and $A$. pacificus requires seawater medium for growth, utilizes glucose and fructose, and is not able to denitrify. Moreover, the name " $A$. denitrificans," published in 1954, would have priority over the other names, which were proposed between 1955 and 1978. Therefore, the species name Alcaligenes denitrificans is here revived.

Description of $A$. denitrificans sp. nov. nom. rev., based on the type strain, NCTC $\mathbf{8 5 8 2}^{\mathrm{T}}$. The cells are gram-negative, short rods with rounded ends and occur singly, in pairs, or short chains. The average size is 0.7 to $1.0 \mu \mathrm{m}$ by 1.2 to 3.0 $\mu \mathrm{m}$ as measured by phase-contrast microscopy. The cells are motile and peritrichous.

Morphological characteristics: colonies on agar are circular with an entire margin, flat, smooth, nonpigmented, translucent, and 1 to 2 $\mathrm{mm}$ in diameter. Good growth occurs in nutrient broth with uniform turbidity.

Physiological growth characteristics: aerobic, but capable of anaerobic respiration in the presence of nitrate or nitrite. The cells are mesophilic; growth occurs at temperatures between 10 and $37^{\circ} \mathrm{C}$, and the optimal growth temperature is $24^{\circ} \mathrm{C}$. The highest concentrations of $\mathrm{NaCl}$ permitting growth are 3.5 to $4.5 \%$. Prototrophic.

Nitrate reduced to nitrite and gas. Gas produced from nitrite. Nitrate and nitrite, as sole sources of nitrogen, support growth.

Oxidase and catalase are produced. Indole, acetylmethylcarbinol, hydrogen sulfide, and fluorescent pigment in King medium B are not 
produced. Traces of ammonia are generated from peptone. Methyl red test is negative. No change in litmus milk.

Gelatin and casein are not digested. Urease, arginine dihydrolase, lysine decarboxylase, ornithine decarboxylase, and extracellular DNase are not produced.

No acid from arabinose, fructose, glucose, glycerol, lactose, maltose, mannitol, sucrose, or xylose within 42 days.

Lipid, chitin, starch, and alginate are not hydrolyzed.

D-Glucose, D-galactose, D-fructose, and Dmannose are not utilized as sole sources of carbon, but growth occurs with sodium acetate, sodium succinate, sodium glutamate, and citrate.

DNA base composition: $69.1 \pm 0.3 \mathrm{~mol} \%$ $\mathrm{G}+\mathrm{C}\left(T_{m}\right.$ estimation).

Pichinoty et al. (17) reported the following nutritional tests as positive for " $A$. denitrificans": utilization of D-saccharate, adipate, pimelate, suberate, $\beta$-hydroxy- $\beta$-methyl-glutarate, meso-tartrate, azelate, and itaconate.

The description of $A$. faecalis given by Holding and Shewan in Bergey's Manual of Determinative Bacteriology, 8th ed. (10) is based on the publication of Hendrie et al. (9), including the characteristics of $A$. faecalis Castellani and Chalmers 1919, "A. odorans" (Málek and Kazdová-Kožišková) Málek, Radochová and Lysenko 1963, "A. denitrificans" Leifson and Hugh 1954, and "Achromobacter arsenoxydans-tres" Turner 1954. Due to the separation of $A$. denitrificans from $A$. faecalis, the description of $A$. faecalis in Bergey's Manual of Determinative Bacteriology, 8th ed. (10) has to be changed as follows.

A yellow fluorescent pigment is produced in King medium B; ammonium, but neither nitrate nor nitrite is used as a sole source of nitrogen; nitrate is not reduced to nitrite and gas, but gas is produced from nitrite in mineral media containing ammonium. According to Pichinoty et al. (17), A. faecalis CIP $6080^{\mathrm{T}}\left(=\mathrm{DSM} 30030^{\mathrm{T}}\right)$ did not utilize D-saccharate, adipate, pimelate, suberate, $\beta$-hydroxy- $\beta$-methylglutarate, meso-tartrate, azelate, and itaconate.

\section{LITERATURE CITED}

1. Bradley, S. G. 1973. Relationships among mycobacteria and nocardia based upon deoxyribonucleic acid reassociation. J. Bacteriol. 113:645-651.

2. Bradley, S. G., and M. Mordarski. 1976. Association of polydeoxyribonucleotides of deoxyribonucleic acids from nocardioform bacteria, p. 310-336. In M. Goodfellow, G. H. Brownell, and J. A. Serrano (ed.), The biology of the nocardiae. Academic Press, Inc., New York.

3. Brock, T. D. 1979. Biology of microorganisms, 3rd ed., p. 428. Prentice-Hall, Inc., Englewood Cliffs, N.J.

4. Burkholder, P. R. 1963. Some nutritional relationships among microbes of sea sediments and waters, p. 133-150. In C. H. Oppenheimer (ed.), Symposium on marine mi- crobiology. Charles C Thomas, Publisher, Springfield, Ill.

5. De Ley, J. 1970. Reexamination of the association between melting point, buoyant density, and chemical base composition of deoxyribonucleic acid. J. Bacteriol. 101:738-754.

6. De Ley, J., H. Cattoir, and A. Reynaerts. 1970. The quantitative measurement of DNA hybridization from renaturation rates. Eur. J. Biochem. 12:133-142.

7. De Ley, J., K. Kersters, J. Kahn-Matsubara, and J. M. Shewan. 1970 Comparative D-gluconate metabolism and DNA base composition in Achromobacter and Alcaligenes. Antonie van Leeuwenhoek J. Microbiol. Serol. 36:193-207.

8. Gillis, M., J. De Ley, and M. De Cleene. 1970. The determination of molecular weight of bacterial genome DNA from renaturation rates. Eur. J. Biochem. 12:143153

9. Hendrie, M. S., A. J. Holding, and J. M. Shewan. 1974. Emended descriptions of the genus Alcaligenes and of Alcaligenes faecalis and proposal that the generic name Achromobacter be rejected: status of the named species of Alcaligenes and Achromobacter. Int. J. Syst. Bacteriol. 24:534-550.

10. Holding, A. J., and J. M. Shewan. 1974. Genus Alcaligenes Castellani and Chalmers 1919 , p. 273-275. In R. E. Buchanan and N. E. Gibbons (ed.), Bergey's manual of determinative bacteriology, 8 th ed. The Williams \& Wilkins Co., Baltimore.

11. Leifson, E., and R. Hugh. 1954. Alcaligenes denitrificans n. sp. J. Gen. Microbiol. 11:512-513.

12. Málek, I., M. Radochová, and O. Lysenko. 1963. Taxonomy of the species Pseudomonas odorans. J. Gen. Microbiol. 33:349-355.

13. Mandel, M., and J. Marmur. 1968. Use of ultraviolet absorbance-temperature profile for determining the guanine plus cytosine content of DNA. Methods Enzymol. 12:195-206.

14. Marmur, J. 1961. A procedure for the isolation of deoxyribonucleic acid from micro-organisms. J. Mol. Biol. 3:208-218.

15. Marmur, J., and P. Doty. 1962. Determination of the base composition of deoxyribonucleic acid from its thermal denaturation temperature. J. Mol. Biol. 5:109-118.

16. Mayer, J., K. Brys, and I. Odler. 1973. Vereinfachung des bakteriologischen Nitratreduktionstestes mit Merckoquant 10007 . Zentralbl. Bakteriol. Parasitenkd. Infektionskr. Hyg. Abt. 1. Orig. Reihe B. 157:283-286.

17. Pichinoty, F., M. Véron, M. Mandel, M. Durand, C. Job, and J.-L. Garcia. 1978. Étude physiologique et taxonomique du genre Alcaligenes: $A$. denitrificans, A. odorans et $A$. faecalis. Can. J. Microbiol. 24:743-753.

18. Rüger, H.-J., and G. Richter. 1979. Bacillus globisporus subsp. marinus subsp. nov. Int. J. Syst. Bacteriol. 29:196-203.

19. Seiler, H. 1979. Taxonomische Untersuchungen über Acinetobacter aus Oberflächenwasser. Arch. Hydrobiol. 85:57-71

20. Skerman, V. B. D., V. McGowan, and P. H. A. Sneath (ed.). 1980. Approved lists of bacterial names. Int. J. Syst. Bacteriol. 30:225-420.

21. Sneath, P. H. A., and V. G. Collins. 1974. A study in test reproducibility between laboratories: report of a $P$ seudomonas Working Party. Antonie van Leeuwenhoek J. Microbiol. Serol. 40:481-527.

22. Stanier, R. Y., N. J. Palleroni, and M. Doudoroff. 1966. The aerobic pseudomonads: a taxonomic study. J. Gen. Microbiol. 43:159-271.

23. Sueoka, N. 1961. Variation and heterogeneity of base composition of deoxyribonucleic acids: compilation of old and new data. J. Mol. Biol. 3:31-40.

24. Weyland, H., H.-J. Rüger, and H. Schwarz. 1970. Zur Isolierung und Identifizierung mariner Bakterien. Ein Beitrag zur Standardisierung und Entwicklung adäquater Methoden. Veröff. Inst. Meeresforsch. Bremerhaven 12:269-296. 